\title{
EFFICACY OF ANTIBIOTIC APPROACHES IN NEWBORNS AND INFANTS WITH NASOLACRIMAL DUCT OBSTRUCTION
}

\author{
ROXANA CALMUSCHI (TRINC) ${ }^{1,2 \#}$, FLORIN ADRIAN SZASZ ${ }^{3 \#}$, SORIN TRINC ${ }^{2 *}$, SILVIA \\ ROBU $^{4 \#}$, DANA TUTUNARU ${ }^{4}$, IONELA DANIELA MORARIU ${ }^{5 \#}$, AFILON JOMPAN $^{1}$ \\ 1 "Vasile Goldiș” Western University of Arad, Faculty of Medicine, Arad, Romania \\ ${ }^{2}$ Arad County Clinical Hospital, Department of Ophtalmology, Arad, Romania \\ ${ }^{3}$ University of Medicine and Pharmacy Oradea, Department of Obstetrics-Gynecology, Oradea, Romania \\ 4 "Dunărea de Jos" University, Faculty of Medicine and Pharmacy, Galați, Romania \\ 5 "Grigore T. Popa" University of Medicine and Pharmacy, Faculty of Pharmacy, Iaşi, Romania
}

*corresponding author: sorintrinc@yahoo.com

${ }^{*}$ Authors with equal contribution

\begin{abstract}
The maximal incidence of nasolacrimal duct obstruction (NLDO) is in new-borns and infants due to the minimal development and anatomy of the nasolacrimal duct, to the declive predominant position and to the inefficient local cleaning. We analysed the paraclinical investigations and treatment modalities in patients from Ophthalmology department in Arad County Clinical Hospital (Arad CCH) between 2016 and 2017. Most of the NLDO patients developed cultures of positive lacrimal secretions, with or without clinical signs, of which the most common Gram $(+)$ germ $(68 \%)$ was Staphylococcus aureus $(50 \%)$ while the most common Gram(-) germ was Haemophilus influenzae $(8.63 \%)$ of the total number of patients. These results are similar to the average quoted in the specialized literature. According to antibiogram, the Gram $(+)$ germs were most susceptible to Netilmycin and Levofloxacin and Gram(-) germs were the most susceptible to Ciprofloxacin. All patients with visible symptoms of superinfection of the lacrimal ducts developed positive cultures, while only $33.73 \%$ of those with epiphora showed bacterial growth in conjunctival secretions. It demonstrated the inefficiency of antibiotic treatment in $66.27 \%$ of patients with simple epiphora without first having a specialized ophthalmological examination with analysis of conjunctival secretions. Self-medication in those cases leads to alteration of lacrimal film composition and uncontrolled resistance to antibiotics.
\end{abstract}

\section{Rezumat}

Incidența maximă a obstrucției de canal lacrimonazal (OCNL) apare la nou născuți și la sugarul mic datorită anatomiei canalului lacrimonazal dezvoltat ineficient, a poziției predominant declive și a lipsei toaletei locale eficiente. Studiul cuprinde investigațiile paraclinice și modalităţile de tratament propuse pacienților cu OCNL în cadrul Compartimentului de Oftalmologie al Spitalului Clinic Județean Arad în perioada 2016 - 2017. Majoritatea pacienților cu OCNL au dezvoltat culturi din secreții lacrimale pozitive, cu sau fără semne clinice, dintre aceștia cel mai frecvent germen Gram + a fost Staphylococcus aureus (50\%), iar cel mai frecvent germen Gram - a fost Haemophylus influenzae (8,63\%) din totalul pacienților, rezultate care se apropie de media citate in literatura de specialitate. Conform cu antibiograma, sensibilitatea maximă la antibiotice a germenilor Gram(+) a fost la netilmicină și levofloxacină iar a celor Gram(-) la ciprofloxacină. Toți pacienții cu simptome vizibile de suprainfecție a căilor lacrimale (secreții purulente) au dezvoltat culturi pozitive, in vreme ce doar $33,73 \%$ din cei cu epifora au prezentat dezvoltare bacteriana in secrețiile conjunctivale. Acest lucru demonstrează nulitatea tratamentului cu antibiotic la $66,27 \%$ din pacienții pediatrici cu epiforă înaintea unui consult de specialitate oftalmologic și a efectuării culturii din secreții conjunctivale. Astfel, automedicația în aceste cazuri provoacă alterarea compoziției filmului lacrimal si creșterea rezistentei la antibiotice.

Keywords: OCNL, antibiotics, efficacy, susceptibility

\section{Introduction}

Approximately $30-40 \%$ of new-borns, infants and young children have some symptoms of NLDO (nasolacrimal duct obstruction). The most common cause is the persistence of a tissue membrane over the Valve of Hasner at the end of the nasolacrimal duct $[10,11]$. Primary symptoms are epiphora leading to excess overflow of tears due to nasolacrimal duct blockage - crusts and secretions in the periocular area due to lacrimal system infections. The
NLDO diagnosis is determined by the ophthalmologist but can also be recognized by the General Practitioner or paediatrician $[2,4,5]$.

Very often the disease is not correctly diagnosed, being labelled as conjunctivitis and the favourable results are delayed both by postponing the mechanical intervention - probing the nasolacrimal duct, but also by exaggerating its indications. The symptoms are reduced in intensity and the bacteria and other microorganisms which appear in conjunctival secretions 
FARMACIA, 2019, Vol. 67, 5

are from the normal cutaneous flora. The infections of the lacrimal secretions are determined by the stagnation of the bacterial microorganisms in the wet and hot medium from the lacrimal sac [16]. The treatment methods indicated by the ophthalmologist are local washout with saline solution and local pressure of the lacrimal duct and sac and, in selected cases, nasolacrimal probing when local antibiotic treatment can be added $[4,8]$.

Generally local antibiotic treatment is inappropriate and wrongly prescribed. It is useful only when complications occur and, in the situations, when the patient's condition isn't assessed in a timely manner. The wrongful administration of topical antibiotics to infants leads to a change in the quality of the lacrimal film and to the increase in germ resistance to antibiotics $[10,13,15]$.

The purpose of this study is to establish a NLDO treatment protocol in new-borns and infants, a guide regarding the usefulness of topic antibiotic administration determined by the ophthalmological examination and by the sensibility of lacrimal secretions' germs to antibiotics. The nasolacrimal pressure and the local washout with saline solution have a considerable clinical importance, usually ignored by the family of the patient and by the majority of the ophthalmologists and pharmacists $[1-3,8]$. This study also determines the microbiological agents responsible for the superinfection of lacrimal secretions in cases of confirmed NLDO and their susceptibility to the usual antibiotics, with a role in establishing the therapeutic method of choice, and the prevalence of NLDO diagnostic and germs superinfection in distinct age groups [10].

\section{Materials and Methods}

Study group

The study included 115 patients (139 eyes) diagnosed with NLDO in the Outpatient Ophthalmology of Arad $\mathrm{CCH}$ during 1.01.2016 - 31.12.2017, aged between 0.5 and 36 months, and diagnosed with NLDO using specific methods: ophthalmologic examination, biomicroscopic examination, fluorescein tests, Schirmer tests and probing of the nasolacrimal duct for diagnostic purposes. Those patients that used antibiotics a week before collecting the conjunctival secretions and those with conjunctivitis, blepharitis, chalazion or hordeolosis were excluded from the study. The parents/tutors were informed about the study and their consent was obtained. The study was authorized by the "Vasile Goldiş" West University Faculty of Medicine Ethics Committee, according to the Declaration of Helsinki.

Collection of specimens

The collection of specimens was performed in the consultation room by expressing the lower lacrimal punctum and extracting the secretions using the lacrimal duct probe kit provided by the microbiological analysis laboratory, in sterile conditions. Cultures and antibiograms

The culture and antibiogram of the conjunctival secretions collected from patients with NLDO were performed using the secretion sample obtained by expressing the lower lacrimal punctum and the conjunctival sac. The mucopurulent serum material was then collected on sterile sticks and seeded on environments like MacConkey agar, Chocolate agar, BHI (Brain Heart Infusion) Broth.

The medium was incubated at $37^{\circ} \mathrm{C}$ for $24-48$ hours. The culture on Chocolate agar medium was incubated at $37^{\circ} \mathrm{C}$ in the presence of $5-10 \%$ of $\mathrm{CO}_{2}$ for $24-48$ hours. Positive culture was defined as the growth of the same type of organism in more than two phases of incubation or confluent growth on a solid medium. Cultures also show susceptible fungi according to the characteristics of the colonies, the growth rate and the diffuse presence of the pigment. Gram stain was used to identify bacteria and possible fungi, while the susceptibility to the antibiotics was tested using the classic method. The application of microtablets was made with sterile forceps, pressing gentle each micro tablet on the surface of the medium. A distance of $\sim 15 \mathrm{~mm}$ from the edge of the board and $\sim 30 \mathrm{~mm}$ between micro tablets was respected. Various kits of antimicrobial/antifungal substances were used according to the type of germ identified: coccus, bacillus or fungi and the nature of the product from which the microbe was isolated.

The discs impregnated with a fixed amount of active substance were clearly marked on both sides with the symbol of the specific antibiotic/antifungal substance. Preservation of micro tablets was done by keeping them away from heat, light and humidity. Preparations were strictly used before the expiration date. By placing antibiotic micro tablets on the surface of a solid medium sown with the bacterial/fungicidal suspension that needs to be tested, the active antimicrobial/antifungal substance diffuses into the medium and produces a culture inhibition zone according to the bacterial/fungal culture sensitivity.

The incubation period was 16 - 18 hours; only in most urgent situations a preliminary reading was made after 4 - 6 hours. Only those boards showing a growth of the appropriate culture in terms of purity and density (dense culture almost confluent) were read. Reading was done with the naked eye, measuring the diameter of the inhibition zone in $\mathrm{mm}, 2$ - 3 times in different directions, using a ruler. If the medium was transparent, the reading could be performed directly on the bottom of the board, while on the blood-gelled boards the diameters of the inhibition zone were measured at the surface of the medium. The diameters of the inhibition zones were considered: the area free from naked eye visible microbial colonies, including the diameter of the 
antibiotic disc, as well as the well-developed colonies within the inhibition zone. They may be resistant mutants within a predominantly sensitive microbial population; they will replicate and retest.

\section{Results and Discussion}

Demographic data

Valid cultures were obtained from 115 patients (139 eyes) diagnosed with NLDO. The average age was 5.42 months and the majority of the patients were boys $(58.2 \%)$. Samples were obtained from both eyes in case of $20.86 \%$ patients while the rest of the samples were collected only from one affected eye. Age repartition was the following: 0.5 - 3 months: 41 patients; 4 - 6 months: 25 patients; 7 - 9 months: 10 patients; 10 - 12 months: 11 patients; $13-36$ months: 5 patients (Figure 1).

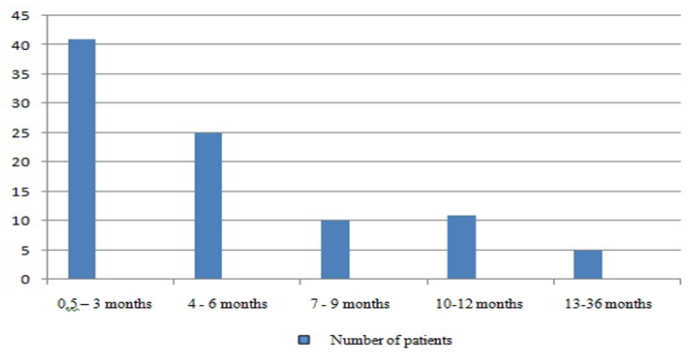

Figure 1.

Age distribution of patients with NLDO
From our data NLDO appears most frequently in the first 3 months of life $(35.65 \%)$ due to the anatomy of the lacrimal duct, lack of remission of the Hasner membrane from the lacrimal duct, predominant supine position of the new-born and lack of constantly local washout with saline solution.

Parents' growing concern for the remittance of lacrimal secretions in infants leads frequently in self-medication with antibiotics without a medical prescription $[3,5]$. Therefore, the present study demonstrates the real necessity of topical antibiotic administration and the results of the therapeutic algorithms.

Of the 139 samples, 55 (39.5\%) did not develop positive cultures and in 84 cases - 13 microorganisms were found. Out of these 84 cases, $68(80.95 \%)$ were Gram-positive and 14 cases $(19.05 \%)$ were Gramnegative. In total 84 isolated germs were determined. No fungi were detected in the studied cultures.

The most frequently isolated Gram-positive microorganism was Staphylococcus aureus (42 cases or $50 \%$ ) coagulase negative, and the most frequently isolated Gram-negative microorganism (11 cases or 78\%) was Haemophilus influenzae. In patients under the age of 12 months the Gram-positive germs were found with higher frequency while in those over the age of 12 months Gram-negative germs were isolated (Table I).

Table I

Germs isolated in NLDO

\begin{tabular}{|c|c|c|c|c|}
\hline Type & Germs & $\begin{array}{c}\text { Number of } \\
\text { cases }\end{array}$ & Total positive cases & Susceptibility to antibiotic \\
\hline \multirow{7}{*}{$\begin{array}{c}\text { Gram } \\
(+)\end{array}$} & Staphylococcus aureus & 42 & $50 \%$ & Netylmycin $(90.47 \%)$ \\
\hline & Streptococcus pneumoniae & 16 & $19.04 \%$ & Levofloxacin $(62.57 \%)$. \\
\hline & Staphylococcus epidermidis & 5 & $5.95 \%$ & Netylmycin \\
\hline & $\beta$-haemolytic streptococcus Group C & 2 & $2.94 \%$ & Netylmycin \\
\hline & Staphylococcus lugdunensis & 1 & $1.19 \%$ & Netylmycin \\
\hline & $\beta$-hemolytic streptococcus & 1 & $1.19 \%$ & Netylmycin \\
\hline & Enterococcus faecalis & 1 & $1.19 \%$ & Netylmycin \\
\hline \multirow{6}{*}{$\begin{array}{c}\text { Gram } \\
(-)\end{array}$} & Haemophilus influenzae & 11 & $13.9 \%$ & \multirow{6}{*}{$\begin{array}{c}\text { Ciprofloxacin }(100 \%) \\
\text { Azithromycin }(68.75 \%) \\
\text { Levofloxacin }(62.5 \%)\end{array}$} \\
\hline & Escherichia coli & 1 & $1.19 \%$ & \\
\hline & Acinetobacter baumani & 1 & $1.19 \%$ & \\
\hline & Citrobacter freundii & 1 & $1.19 \%$ & \\
\hline & Klebsiella oxytoca & 1 & $1.19 \%$ & \\
\hline & Haemophilus parainfluenzae & 1 & $1.19 \%$ & \\
\hline
\end{tabular}

Susceptibility of bacteria from studied cultures to antibiotics

Concerning $\operatorname{Gram}(+)$ bacteria, the highest susceptibility to antibiotics was found in Netilmycin (38 cases out of 42 Staphylococcus aureus positive cultures or $90.47 \%$ ) and Levofloxacin (10 out of 16 cases of Streptococcus pneumoniae positive cultures or $62.57 \%$ ). In the case of Gram(-) bacteria maximum susceptibility to antibiotic was found in Ciprofloxacin (14 cases or $100 \%)$. Isolated cases of atypical germs such as Enterococcus fecalis (1 case), Staphylococcus lugudensis (1 case), Acinetobacter baumani (1 case), Citrobacter freundi (1 case), Kllebsiella (1 case), these were susceptible to Ciprofloxacin in $100 \%$ of the cases. Azithromycin was successfully tested in 11 cases (68.75\%) and Levofloxacin in 10 cases (62.5\%).

All antibiotics used in our study were under direct recommendation of the specialist and in accordance with the consent of the parents, but inadequate or excessive use of antibiotic may lead to resistance of microorganisms $[3,7,14]$. There is also evidence that improper use of antibiotic eye drops can affect negatively the treatment process, especially in young children $[5,13,15]$. 
Subgroup analysis

The results of the bacteriological analysis were studied according to the patient's symptoms: simple epiphora or the history of purulent lacrimal secretions. The distribution of results in this respect is presented in the Table II.

Table II

Bacteriological results by patient's symptomatology

\begin{tabular}{|c|c|c|}
\hline & $\begin{array}{c}\text { Simple } \\
\text { epiphora }\end{array}$ & $\begin{array}{c}\text { Purulent } \\
\text { lacrimal secretions }\end{array}$ \\
\hline & 83 cases & 56 cases \\
\hline Positive culture & $28(33.73 \%)$ & $56(100 \%)$ \\
\hline G(+) bacteria & $20(71.43 \%)$ & $37(66.07 \%)$ \\
\hline G(-) bacteria & $8(28.57 \%)$ & $19(33.93 \%)$ \\
\hline
\end{tabular}

It is observed that in just $33.73 \%$ of cases of simple epiphora the lacrimal secretion cultures tested positive, thus limiting the antibiotic treatment only to those cases. The total positivity in all patients was of $73.04 \%$. The Prevalence of $\mathrm{G}(+)$ germs was higher than that of G(-) germs. Based on the microbiological results obtained, the patients were divided in terms of therapy, in 4 groups: Group 1 - Negative culture, medium epiphora - 37 patients - nasolacrimal sac massage; Group 2 - Negative culture, massive epiphora - 18 patients - nasolacrimal probing; Group 3 - Positive culture, medium epiphora - 69 patients - nasolacrimal duct massage combined with antibiotics according to the antibiogram; Group 4 - Positive culture, massive epiphora - 15 patients - nasolacrimal duct probing combined with antibiotics according to the antibiogram. In positive cultures for Gram-positive germs we used topical administration of Netilmycin and Levofloxacin. Moreover, azithromycin and levofloxacin were used for the treatment of patients under the age of 1 year that tested positive for Gram-negative germs or atypical bacteria. In these cases, ciprofloxacin is not recommended.

Regarding the treatment of the first group, from a total of 37 patients, full remission of symptoms was obtained in 30 patients, while in 7 cases probing was recommended. Concerning the second group, from a total of 18 patients, single probing of nasolacrimal duct was efficient in 15 patients, while in 3 cases a second intervention by probing was recommended to be conducted in 60 days. In the third group of patents, from a total of 69 , a full remission of symptoms was noticed in 57 cases treated with nasolacrimal duct massage combined with topical administration of antibiotics, while 12 patients also needed probing. Within the fourth group, from a total of 15 patients with recommendation of nasolacrimal duct probing combined with topical administration of antibiotics, positive results were recorded in all patients. For a comprehensive statistic of the efficiency of treatment in the four groups we used the CHI squared test $\chi^{2}$. The obtained value was 3.222 , which indicates an error of $35.9 \%$, and we could conclude that there are no significant differences in the investigated groups regarding the clinical efficiency (Figure 2).

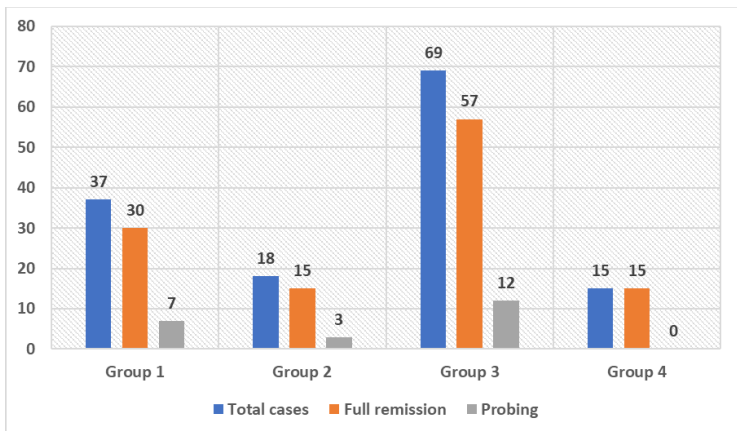

Figure 2.

Treatment results for the four groups of children

Furthermore, two tailed paired t test was used to correlate the efficiency of the pairing $(r=0.9819$, $\left.\mathrm{R}^{2}=0.6043, \mathrm{t}=2.471, \mathrm{df}=4\right)$. All these statistic parameters indicate that the obtained results correlate to the pairing and there is a significant statistic difference between the number of cured/not cured patients. Moreover, in all groups we obtained a high percent (over $80 \%$ ) of remissions.

There is still great controversy regarding the best management of NLDO. The most conservative view is that NLDO is to be treated in the first year of life by applying effective lacrimal sac massage. Some patient observational studies confirm that such a method is efficient if the parents were strict with the lacrimal sac massage in the follow-up period, but it took longer to resolve when parents did not apply the massage on regular basis $[5,9,15]$. Our results obtained for the group 1 and 3 confirm such observations.

The maximal incidence of NLDO is in new-borns and infants $(33.65 \%)$ due to the minimal development and anatomy of the nasolacrimal duct. For the efficiency of the treatment it is also important to know where the site of stenosis is located along the nasolacrimal duct, so that the proper therapeutic algorithm should be recommended $[6,11,12]$. For our study, most of the NLDO patients developed cultures of positive lacrimal secretions, with or without clinical signs, of which the most common Gram(+) germ $(68 \%)$ was Staphylococcus aureus (50\%) while the most common Gram(-) germ was Haemophilus influenzae (8.63\%) of the total number of patients. These results are similar to the average quoted in the specialized literature. Gram $(+)$ germs were most susceptible to Netilmycin and Levofloxacin and Gram(-) germs were the most susceptible to Ciprofloxacin. All patients with visible symptoms of superinfection of the lacrimal ducts developed positive cultures, while only $33.73 \%$ of those with epiphora showed bacterial growth in conjunctival secretions. It demonstrated the inefficiency of antibiotic treatment in $66.27 \%$ of patients with 
simple epiphora without first having a specialized ophthalmological examination with analysis of conjunctival secretions. Self-medication in those cases leads to alteration of lacrimal film composition and uncontrolled resistance to antibiotics.

\section{Conclusions}

We insist over the important role of the paediatricians and pharmacists regarding the recommendations given to the parents of the patients with NLDO without being consulted by an ophthalmology specialist. In incipient cases, the most efficient treatment is local saline solution washout and lacrimal duct pressure. For the proper management of NLDO in the first year of life, the parents play an important role in applying regular lacrimal sac massage. In late presentations, the optimal therapeutic method is local lacrimal duct pressure with nasolacrimal probing. Nevertheless, topical use of antibiotics is important when lacrimal secretion is positive for bacteria and is highly recommended to further eliminate complications of the eyesight.

\section{References}

1. A randomized trial comparing the cost-effectiveness of 2 approaches for treating unilateral nasolacrimal duct. (American Ophthalmological Society thesis). Trans Am Ophthalmol Soc., 2012; 110: 74-93.

2. Becker BB, Berry FD, Koller H, Balloon catheter dilatation for treatment of congenital nasolacrimal duct obstruction. Am J Ophthalmol., 1996; 121: 304-309.

3. Cristescu C, Negres S, Suciu M, Voicu A, Buda V, Suciu L, Proks M, Voicu M, Study regarding the parents' use of self-medication among children under 12 years old. Farmacia, 2018; 66(5): 811-819.

4. Engel JM, Hichie-Schmidt C, Khammar A, Ostfeld BM, Vyas A, Ticho BH, Monocanalicular silastic intubation for the initial correction of congenital nasolacrimal duct obstruction. $J A A P O S, 2007 ; 11$ : 183-186.

5. Karti O, Karahan E, Acan D, Kusbeci T, The natural process of congenital nasolacrimal duct obstruction and effect of lacrimal sac massage. Int Ophthalmol., 2016; 36: 845-849.

6. Katowitz WR, Nazemzadeh M, Katowitz JA, Initial management of pediatric lower system problems: Probing and silicone stents and balloons. In: Katowitz J., Katowitz W. (eds) Pediatric Oculoplastic Surgery. Springer, Cham, 2018, 479-500.

7. Morariu ID, Avasilcăi L, Vieriu M, Cioancă O, Hăncianu M, Immunochemical assay of chloramphenicol in honey. Farmacia, 2019; 67 (2): 235-239.

8. Paul TO, Shepherd R, Congenital nasolacrimal duct obstruction: Natural history and the timing of optimal intervention. J Pediatr Ophthalmol Strabismus, 1994; 31: 362-367.

9. PEDIG. A randomized trial comparing the costeffectiveness of 2 approaches for treating unilateral nasolacrimal duct obstruction. Arch Ophthalmol., 2012; 130(12): 1525-1533.

10. Pornpanich K, Luemsamran P, Leelaporn A, Santisuk $\mathrm{J}$, Tesavibul N, Microbiology of primary acquired duct obstruction: simple epiphora, acute dacryocystitis and chronic dacryocystitis. Clinical Ophtalmology, 2016;10: 337-342.

11. Repka MX, Chandler DL, Beck RW, Crouch ER $3^{\text {rd }}$, Donahue S, Holmes JM, Lee K, Melia M, Quinn GE, Sala NA, Schloff S, Silbert DI, Wallace DK, Primary treatment of nasolacrimal duct obstruction with probing in children younger than 4 years. Ophthalmology, 2008; 115: 577-584.

12. Takahashi Y, Kakizaki H, Chang WO, Selva D, Management of congenital duct obstruction. Acta Opthalmol., 2010; 88: 506-513.

13. Usha K., Smitha S., Shah N., Lalitha P., Kelkar R, Spectrum and the susceptibilities of microbial isolates in cases of congenital nasolacrimal duct obstruction. $J$ AAPOS, 2006; 10(5): 469-472.

14. Voicu M, Cristescu C, Zbârcea CE, Voicu A, Buda V, Suciu L, Suciu M, Proks M, Bild V, Comparative study of antimicrobials use and the antibiotic resistance of Gram negative strains. Farmacia, 2017; 65(2): 225-229.

15. Young JDH, MacEwen CJ, Ogston SA, Congenital nasolacrimal duct obstruction in the second year of life: a multicentre trial of management. Eye, 1996; 10: 485-491.

16. Zappia RJ, Milder B, Lacrimal drainage function: 2. The fluorescein dye disappearance test. $A m J$ Ophthalmol., 1972; 74: 160-163. 